\title{
FABRIKAS «PROVODN,IK» DARBĪBA RĪGĀ UN TĀS DARBINIEKI - RĪGAS POLITEHNIKUMA / RĪGAS POLITEHNISKĀ INSTITŪTA ABSOLVENTI
}

\section{ALİDA ZIGMUNDE* \\ Rīgas Tehniskā universitāte \\ OLEGS ŠAPOVALOVS \\ «Provodṇik» / Rīgas elektromašīnbūves rūpnīcas muzejs}

Kopsavilkums. Rakstā dots pārskats par 1888. gada jūnijā Rīgā, Sarkandaugavā, nodibinātā krievu un franču kopuzñēmuma - gumijas, gutaperčas un telegrāfa piederumu fabriku sabiedrības «Provodṇik» darbību. Pirms Pirmā pasaules kara «Provodṇik» kḷuva par vienu no četrām lielākajām gumijas fabrikām pasaulē. 1915. gadā fabriku evakuēja uz Maskavu, 1918. gadā uzṇēmumu nacionalizēja. 1921. gadā akcionāri nolēma fabrikas bijušajās telpās atjaunot «Provodṇik» darbību, bet situācija bija mainījusies. Tā vairākus gadus darbojās kā kokapstrādes rūpnīca (1925-1935), bet nekad nesasniedza tādu uzplaukumu kā 19. gadsimta beigās un 20. gadsimta sākumā. 20. gadsimta 30. gadu beigās likvidēta. Nozīmīgu ieguldījumu «Provodṇik» darbā un attīstībā devuši Rīgas Politehnikuma (RP) un Rīgas Politehniskā institūta (RPI) absolventi, kuri apzināti, veicot dokumentos balstītu pētījumu.

Atslēgas vārdi. «Provodṇik», Rīgas Politehnikums, Rīgas Politehniskais institūts, absolventi rūpniecībā.

\section{Fabrika «Provodṇik» - lielākā gumijas izstrādājumu fabrika Rīgā (1888-1915)}

19. gadsimta 80. gados sākās strauja rūpniecības attīstība Rīgā, Liepājā, Jelgavā un citās lielākajās cariskās Krievijas pilsētās.

\footnotetext{
* Korespondējošais autors.

E-pasts: alida.zigmunde@rtu.lv
} 
Jaundibinātajām fabrikām un akciju sabiedrībām, tostarp arī 1888. gada 26. jūnijāa ${ }^{1}$ nodibinātajai krievu un franču sabiedrības gumijas, gutaperčas un telegrāfa piederumu fabriku sabiedrībai «Provodṇik», bija nepieciešami tūkstošiem strādnieku un inženieru [1]. Pirms tam Rīgā jau darbojās 1864. gadā dibinātā J. V. Mindela gumijas fabrika, kas atradās Pārdaugavā. Tolaik daudzi laucinieki pārcēlās uz dzīvi pilsētā, taču rūpniecības uzṇēmumi nepiedāvāja viṇiem atbilstošas algas. Tā sākās strādnieku aicināšana no Lietuvas, Polijas, Baltkrievijas un pārējiem Krievijas novadiem. Aicinājumi braukt strādāt uz Rīgu bijuši pat publiskās vietās Sibīrijā un «sevišḳi aktīva šinī ziṇā» esot bijusi lielā fabrika «Provodṇik» [2].

Krievu un franču sabiedrības gumijas, gutaperčas un telegrāfu fabrika «Provodṇik» sāka darbu un ēku celtniecību Sarkandaugavas attekas krastā Ganību dambī 31, aiznnemot 13700 kvadrātmetru lielu teritoriju. Ražošana sākās 1889. gadā, un tā arvien paplašinājās, tika uzceltas jaunas ēkas. Fabrikas pamatkapitāls sākumā bija 0,7 miljoni rubl̦u, vēlāk tas, izṇemot krīzes gadus 19. gadsimta beigās, arvien pieauga un 1909. gada 1. janvārī bija jau deviṇi miljoni rubḷu [3]. Fabrika ražoja galošas, un ražošanas apjoms arvien palielinājās, jo pieprasījums bija liels. Bija laiks, kad dienā izgatavoja 45000 pāru šo apavu. Fabrikas galošu ražošanas cehos vien 1907. gadā bija nodarbināti ap 3500 strādnieku [4]. Tika ražotas arī automobilulu, lidmašīnu un velosipēdu riepas, elektrotehniskie izstrādājumi, gumijas un tehniskie izstrādājumi medicīnai, izolācijas materiāli, kabel̦u piederumi, linolejs, rotaḷlietas, telegrāfa aparatūra, viegli pontoni, ūdenslīdēju tērpi un citi izstrādājumi.

1. attēls. Fabrikas pagalms pie galošu noliktavām.

20. gadsimta sākums [4].

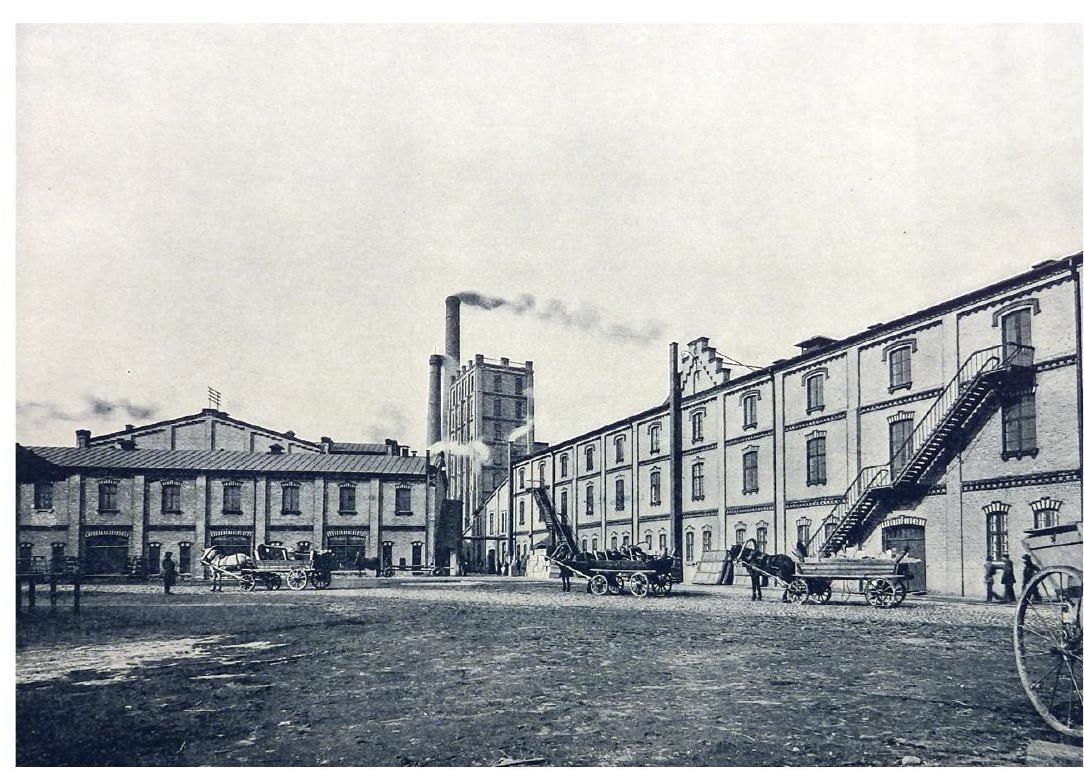

1 Pēc Jūlija kalendāra (vecais stils), pēc Gregora kalendāra (jaunais stils) - 8. jūlijā. 
Izejvielas tika importētas, un 95 \% no saražotā pārdeva Krievijas tirgos. Fabrikai bija preču noliktavas un pārstāvniecības Krievijas un tagadējās Azerbaidžānas, Irānas, K,īnas, Polijas, Somijas, Ukrainas, Uzbekijas un citu valstu pilsētās: Ašhabadā, Astrahaṇā, Baku, Berlīnē, Čenstohovā, Daugavpilī, Gomel̦ā, Harbinā, Harkovā, Helsinkos, Jekaterinburgā, Jekaterinoslavskā, Irkutskā, Kauṇā, Kazaṇā, Kijevā, Kokandā, Kremenčukā, Liepājā, Lodzā, Londonā, Margilonā, Maskavā, Minskā, Nikolajevā, N̦ižnijnovgorodā, Odesā, Omskā, Orenburgā, Orlā, Parīzē, Permā, Pleskavā, Reštā, Rostovā pie Donas, Sanktpēterburgā, Samārā, Samarkandā, Saratovā, Smoḷenskā, Sosnovicā, Stokholmā, Šanhajā, Tallinā, Taškentā, Teherānā, Tbilisi, Tverā, Varšavā, Vilnnā, Vitebskā, Vīnē, Vladivostokā, Volgogradā, Voroṇežā [5]. «Provodṇik» ražojumus pirka arī Anglijā, Vācijā un pa daḷai arī aizokeāna zemēs [6]. Fabrika izpildīja arī Krievijas galma pasūtījumus un pirms Pirmā pasaules kara bija viena no četrām lielākajām gumijas fabrikām pasaulē. Produkcija bija ḷoti kvalitatīva, to pasaulē pazina, tāpēc pēc tās bija pieprasījums [7].

Lai ražotu tik lielā apjomā, bija nepieciešami darbinieki. 1889. gadā «Provodṇikā» strādāja 650 strādnieku, bet pirms Pirmā pasaules kara jau ap 14 000. Dažāds bija strādnieku nacionālais sastāvs. Piemēram, 1897. gadā no 2775 darbiniekiem 1267 bija latvieši, 1254 - lietuvieši un poḷi, 177 krievi, 59 vācieši, 18 igauṇi [8]. Starp citu, uz Rīgu ataicinātie sveštautieši esot jūtami «nosituši» latviešu strādnieku algas [9], taču tad varēja arī krietni pazemināt gumijas izstrādājumu, linoleja un citu preču cenas. Atalgojums bija par iemeslu ekonomiska rakstura streikiem. Piemēram, 1913. gada 17. jūlijā streikoja 100 mehāniksu, 18. jūlijā ap 200 strādnieku [10]. Streiki fabrikā notika diezgan bieži. Strādnieki izgāja ielās jau 1905. gada revolūcijā, bija arī kritušie. Vēlāk tēlnieka Kārḷa Zāles veidotajā Brīvības piemineklī revolūcijai veltītajā bareljefā varam saskatīt arī «Provodṇik» revolucionārus.

Fabrikas izaugsme un panākumi nebija iedomājami bez prasmīgas vadības, kurā strādāja ne viens vien Rīgā studējis inženieris. Bet strādāja arī tādi, kuri te nebija studējuši Rīgā un ieradās no citām pilsētām. Tāds bija Vitebskas guberñā dzimušais Boriss (Venjamins) Vitenbergs (Boris Wittenberg; 1867-1942), kurš Rīgā ieradās un sāka strādāt 1890. gadā. Viṇš beidza komerckursus Maskavā (1897) un 1900. gadā kḷuva par fabrikas izpilddirektoru, bet 1906. gadā - par generāldirektoru un valdes priekšsēdētāju [11]. Fabrikai toreiz bija dažādas problēmas, bet B. Vitenbergs turpināja to attīstīt, paplašināt, lai sasniegtu pasaules līmeni. Nereti fabrikā notika nelaimes gadījumi, jo strādnieki ne vienmēr ievēroja drošības noteikumus. Visi fabrikas strādnieki bija apdrošināti pret nelaimes gadījumiem, un medicīniskā apkalpošana bija labi organizēta. Fabrikas teritorijā bija lazarete ar 20 gultām. Tur strādāja divi ārsti un viens feldšeris. Bija noslēgts līgums arī ar privātu ḳirurǵijas klīniku, kur 
nepieciešamības gadījumā varēja ievietot saslimušos darbiniekus. Ārstēšanās izdevumus sedza «Provodṇik».

No 1906. līdz 1914. gadam Borisa Vitenberga vadībā Sarkandaugavā uzcēla mazbērnu novietni, bērnu patversmi, fabrikas darbinieku dzīvojamās mājas, pirtis, strādnieku klubu un dārzu ar muzikālo paviljonu (blakus Sarkandaugavas stacijai). Visi pakalpojumi «Provodṇik» darbiniekiem bija bez maksas. 1906. gadā laikrakstā «Balss» bija lasāms: «Ja saskaitīt «Provodṇika» izdevumus uz strādnieku un to tuvinieku ārstēšanu, tad iznāk, ka biedrības valde atdod par labu strādniekiem ap 175000 rublı gadā [12].»

Pirmo «Provodṇik» ražošanas ēku projektēšanā piedalījās Rīgas Politehnikuma absolventi Edmunds fon Trompovskis (Edmund von Trompowsky; 1851-1919) un Jans Benedikts Vodzinskis (Jan Benedykt Wodzinski; 1859-1926). Inženierzinātṇu speciāls J. B. Vodzinskis strādāja arī par mācībspēku Rīgas Politehnikumā / Rīgas Politehniskajā institūtā. Gar Sarkandaugavas kanālu bija uzceltas divas lielas noliktavu ēkas. Tās ir pirmās Eiropā monolīta dzelzsbetona konstrukcijas - 266 metri garas un 15 metri augstas, kas celtas pēc Šveices inženiera Robēra Maijāra (Robert Maillart; 1872-1940) projektiem. Tās uzcēla 1913.-1914. gadā. Daḷa no «Provodṇik» ēkām saglabājušās un tiek izmantotas joprojām.

Sākoties Pirmajam pasaules karam, Krievijas k,eizariene Aleksandra Fjodorovna (Александра Фёдоровна; 1872-1918) parūpējās, lai fabrikas teritorijā būtu lazarete ar 50 gultasvietām slimniekiem un ievainotajiem [13]. Fabrikas darbība, sākoties karam, tika traucēta. Daḷa strādnieku tika mobilizēti, nebija iespējams saṇemt izejvielas un produkciju nogādāt patērētājiem un uz noliktavām, tāpēc «Provodṇik» darbība tika pārtraukta, bet 1915. gadā fabriku evakuēja uz Maskavu, un Rīgā palika tikai ēkas.

2. attēls. «Provodṇik» kopskats. 20. gadsimta sākums [14].

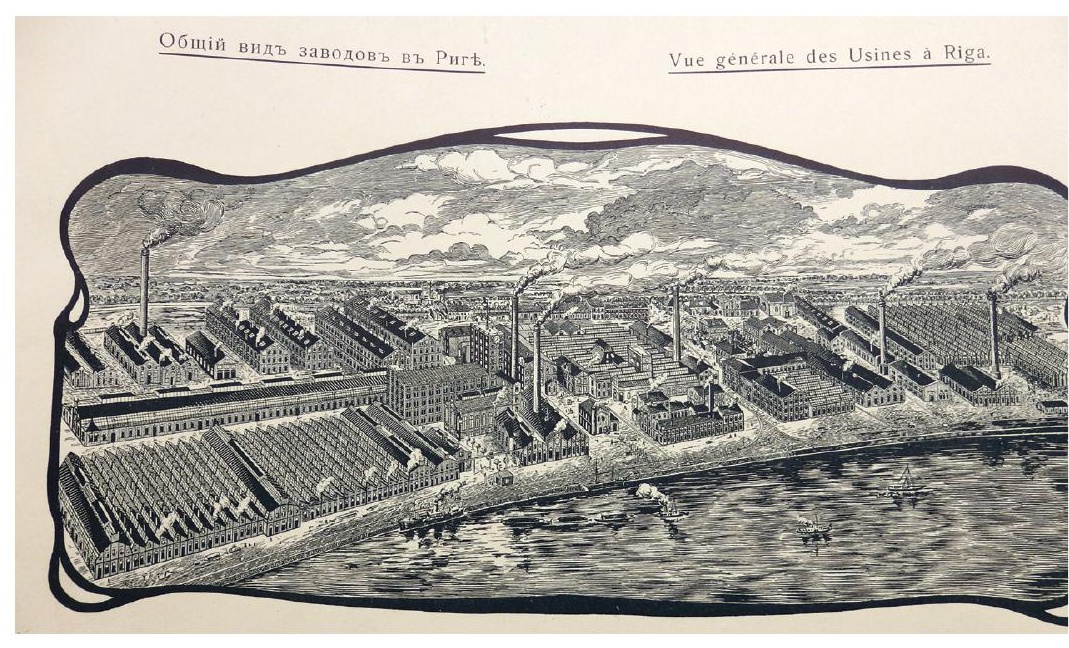


Maskavā tika uzbūvētas vēl trīs rūpnīcas ēkas, 1917. gadā fabrikas darbība tika atjaunota. Kā atceras viens no Rīgas Politehniskā institūta Inženieru nodal̦as absolventiem (1911) Eduards Veiss (1886-1966), «vienā pašā «Provodṇika» jaunbūvē bija 8000 strādnieku, apgrozība 16 miljoni rubḷu. Firmas īpašnieki .. nodaḷu vadītāju un citos nozīmīgos amatos pieñēma tikai rīdziniekus, ja vien varēja dabūt, jo rīdzinieki esot bijuši ar pamatīgām zināšanām, darba mīlestību un godīgumu, nebijuši lielīgi [15].»

\section{«Provodṇik» starpkaru laikā}

Pēc Latvijas Brīvības cīṇām 1920. gada 21. oktobrī Rīgā kopā sanāca «Provodṇik» piecas amatpersonas - direktori Hugo Freijs (Hugo Frey) un Eižens Lindenbergs (Eugen Lindenberg), bijušais direktora amata kandidāts Aleksandrs Klē (Alexander Klee), Uzraudzības padomes locekḷi Jakobs Erhards (Jakob Erhardt) un Maks Rūtenbergs (Max Ruhtenberg) [16]. Bija nolemts atjaunot fabrikas darbu 1921. gada rudenī, un bija paveikti priekšdarbi - Francijā tika pasūtītas iekārtas, Amerikā - jēlvielas. 1921. gada 26. maijā notika «Provodṇik» akcionāru generalsapulce, kurā vienbalsīgi tika nolemts vistuvākajā nākotnē to atjaunot agrākajā apmērā. Par padomes priekšsēdētāju / generāldirektoru, vienbalsīgi ievēlēja pieredzējušo B. Vitenbergu [17]. 1921. gadā tika apstiprināti arī Statūti [18]. B. Vitenbergs bija ticies ar Latvijas Republikas Ministru prezidentu Kārli Ulmani (1877-1942) [19], kā arī finanšu ministru, RPI absolventu (1897) Ringoldu Kalninu (1873-1940) [20], un guvis pārliecību, ka valsts ir stabila un droša. Akcionāri no Francijas bija gatavi ieguldīt lielu naudu. Latvijas valdība atbalstīja šādu lēmumu, jo zināja par fabrikas panākumiem pirms kara un, ja to vēl paplašinātu, tad būtu darbs daudziem valsts iedzīvotājiem. Ieguvēji būtu visi. Boriss Vitenbergs gribējis dabūt koncesiju uz «Provodṇik» īpašumiem Maskavā, kuru boḷševiki bija nacionalizējuši. Tomēr tas viṇam nebija izdevies, tāpat izpalika brauciens uz Maskavu [21]. Mašīnas, dažādas iekārtas bija palikušas Krievijā, tāpēc daḷa akcionāru 1922. gadā iegādājās Mindela gumijas fabriku un izveidoja akciju sabiedrību «Rīgas gumijas manufaktūra "Kontinents»» [22]. Ilggadējais ǵenerāldirektors B. Vitenbergs tajā nedarbojās. "Provodṇik» valde atradās Parīzē, un tās mērḳis bija gūt peḷnu ražojot. Pilnībā atjaunot kādreizējo fabriku nebija iespējams. Akcionāru domas par tās iespējamo darbību Latvijā dalījās, un viṇi nedaudz nogaidīja, cerot, ka darbību izdosies atjaunot vismaz daḷēji. 
Vēlāk administrācija esot satraukusies par jauno muitas tarifu, tāpēc fabrika darbu nesāka [23]. 1924. gadā laikrakstos parādījās ziṇa, ka fabriku nodomājuši pārpirkt šveicieši [24]. "Provodņik» akcionāri bija atvēruši jaunu fabriku «Askim» Norvēgijā. Tā dienā esot izgatavojusi 2500 pāru galošu, ražojumi esot bijuši paredzēti Baltijas un citām Eiropas valstīm. Jaundibināto fabriku vadīja agrākais «Provodṇik» direktors Ervins Kohs (Erwin Koch), kuram ir bijis paredzēts vadošs darbs Rīgā [25]. Bet situācija mainījās, un agrākais gumijas izstrādājumu ražotājs Latvijā darbību šajā jomā neatjaunoja. 1924. gadā sākās likvidācija, tika apzināti akcionāri un vinu ieguldītās naudas summas. Dal̦a no viniem dzīvoja Rīgā, daḷa - ārzemēs. Akcionāru vidū bija arī Rīgas Politehnikuma / Rīgas Politehniskā institūta bijušie studenti un absolventi [26].

1925. gadā likvidētās fabrikas vietā tika izveidota jauna kokrūpniecības akciju sabiedrība «Provodṇik», kas aizṇēma tikai daḷu no kādreizējā «Provodṇik» ēkām un teritorijas. Tās izveidē iesaistījās daḷa kādreizējo akcionāru, vinu vidū bijušais generāldirektors B. Vitenbergs, kurš dzīvoja Francijā, bet bieži apmeklēja Rīgā. Zināms, ka fabrikas brīvās telpas izīrēja, piemēram, Padomju Krievijas «Sovtorgflot» linu noliktavai [27]. Ne vienreiz vien ēkās izcēlās ugunsgrēki, kas iznīcināja gan tur esošās iekārtas, izejvielas un produkciju, gan izpostīja ēkas. Lai gan celtnes bija mūra, jau 19. gadsimtā drīz pēc fabrikas atklāšanas notika pirmais ugunsgrēks. Ēkas atradās tuvu cita pie citas, un starp tām neesot bijis brandmūra. Atjaunotajai akciju sabiedrībai ar uzṇemējdarbību neveicās, tā iekḷuva parādos, un jau 1934. gada nogalē telpas tika izīrētas, bet 1935. gadā sākās pirms 10 gadiem dibinātās kokrūpniecības akciju sabiedrības «Provodṇik» likvidācija [28], kas ilga līdz pat 1940. gadam. Daḷu ēku nojauca, tirgojot k̦ieǵel̦us, flīzes un citus būvmateriālus, daḷu izmantoja citiem mērḳiem. Tā 1937. gada janvārī vienā no bijušā «Provodṇik» korpusiem tika atklāts slēgtais tenisa laukums [29]. «Provodņik» telpās ir atskanējuši arī šāvieni - 1936. gada maijā vecajos korpusos notika šaušanas sacensības policistiem, aizsargiem un armijas pārstāvjiem [30]. Divstāvu ēkas ar trīsstāvu centrālo daḷu Sīmaṇa ielā 14/16, kur nenotika ražošana, 1935. gadā tika izīrētas Rīgas pilsētas Izglīî̀bas valdei, lai tajās izvietotu Rīgas pilsētas 1 . jauktu tautību pamatskolu, 5. vācu pamatskolu, 2. baltkrievu pamatskolu, 6. bibliotēku un 2. rokdarbu darbnīcu [31]. Zināms, ka vēlāk šīs ēkas akciju sabiedrības likvidatori vēlējās pārdot. Pēc Otrā pasaules kara, 1946. gadā, «Provodṇik» korpusos, atjaunojot tos, darbu sāka Rīgas elektromašīnbūves rūpnīca. Vairākums 19. gadsimta beigās un 20. gadsimta sākumā celto ēku joprojām ir apskatāmas un tiek izmantotas dažādiem mērksiem, tostarp ražošanai.
Fabrikas

«Provodnik»

darbība Rīgā un tās darbinieki - Rīgas Politehnikuma / Rīgas Politehniskā institūta absolventi 


\section{Rīgas Politehnikuma / Rīgas Politehniskā institūta absolventi - «Provodņik» darbinieki}

Rīgas Politehnikums tika dibināts, lai nodrošinātu Rīgu, kā arī Baltijas guberņas ar inženieriem. Tas sāka darbu 1862. gadā un 1896. gadā tika reorganizēts par Rīgas Politehnisko institūtu. Laikam ritot, tas sagatavoja arvien vairāk dažādu specialitāšu inženierus: arhitektus, inženierus-tehnologus, ķīmiķus, agronomus, tirdzniecības, mašīnbūves, cel̦u, tiltu, dzelzcel̦u speciālistus. 19. gadsimta 80. gados absolventu skaits pārsniedza pussimtu, bet 90. gados tuvojās simtam. Kulmināciju inženieru sagatavošanā augstskola sasniedza 1903./1904. mācību gadā, kad diplomus saṇēma 229 jaunie inženieri [32]. Rīgā studēja jaunieši no dažādām cariskās Krievijas gubernāām, un pēc studijām viṇi atrada darbu gan plašajā Krievijā, gan ārzemēs. Dal̦a inženieru strādāja dažādos amatos Rīgā, tostarp gumijas, gutaperčas un telegrāfa piederumu fabriku sabiedrībā «Provodņik».

Līdzās generāldirektora amatam, kuru, kā jau minēts, ienēēma Boriss Vitenbergs, kurš nebija studējis Rīgā, fabriku vadīja vēl četri direktori [33]. Šajā augstajā amatā strādājuši Rīgas Politehnikuma Mehānikas (līdz 1896 - Mašīnu inženieru) nodal̦as divi absolventi - Arnolds fon Hertvigs (Arnold von Hertwig; 1859-1928) un Artūrs Fēgedings (Artur Voegeding; 1878-1936). 1887. gada absolvents A. fon Hertvigs fabrikā sāka strādāt 1895. gadā un 1907. gadā kḷuva par tās direktoru. Darbu viṇš turpināja arī Pirmā pasaules kara laikā Maskavā un Rīgā atgriezās 1919. gadā. Nevēloties tikai baudīt vecumdienas un nevarēdams atrast tīkamu nodarbošanos Rīgā, viṇš devās uz Sanktpēterburgu un pārveidoja gumijas fabriku «Треугольник» (trijstūris) atbilstoši jaunākajiem tehnikas sasniegumiem. A. fon Hertviga mūžs noslēdzās Krievijā, apbedīts Rìgā [34].

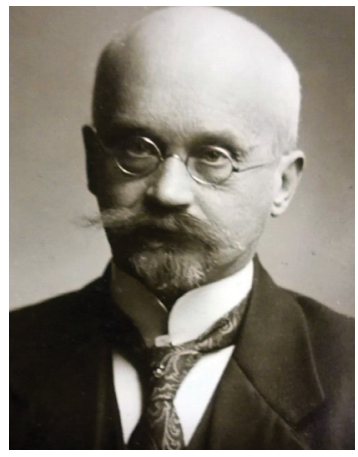

3. attēls. «Provodñik» tehniskais direktors (1917-1919) inženieris Arturs Fēgedings (ap 1927) [35].

1901. gada absolvents Artūrs Fēgedings vispirms strādāja par mācībspēku savā Alma mater (1899-1903), pēc tam - Baltijas vagonu fabrikā 
(1903-1917), Pirmā pasaules kara laikā Maskavā vin,š kḷuva par fabrikas «Provodṇik» tehnisko direktoru (1917-1919). Starpkaru laikā A. Fēgedings strādāja par Vagonu nodaḷas vadītāju Latvijas Valsts dzelzceḷu darbnīcās (1920-1923), šveiciešu inženiera, RP bijušā asistenta Rūdolfa Heinriha Mantela (Rudolph Heinrich Mantel; 1853-1924) privātfirmā (1923-1924), par inženieri AS «Lini» (1924-1926), bet mūža nogalē bija inženieris Rīgas pilsētas ielu dzelzcel̦ā [36].

Ķìmijas tehniskās nodal̦as 1884. gada absolvents Karls Hans Ēmans (Karl Hans Ehmann; 1859-?) strādāja par fabrikas tehnisko direktoru (1889-1901) un 1901. gadā kḷuva par «Provodṇik» pārstāvi Sibīrijas pilsētā Tomskā, Krievijā. 1920. gadā padomju iestādes viṇu arestēja un ieslodzīja koncentrācijas nometnē [37]. Par viṇa tālāko likteni ziṇu nav, taču iespējams, ka viṇš kā optants 1920. gadā ieradās Igaunijā. K. H. Ēmans pretēji komunistiskās varas ideologijai bija ticīgs cilvēks, nebija komunists, aktīvi iesaistījās sabiedriskajā darbā un darbojās vācbaltiešu studentu korporācijā «Fraternitas Baltica», kas Rīgas Politehnikumā tika nodibināta 1865. gadā. Šì un citas studentu mūža organizācijas vienoja to biedrus ne tikai kopīgās idejās, atmiṇās par studiju gadiem un saietos, bet tām bija nozīmīga loma ekonomikas sfērā - savējos iesaistīja dažādu uzṇēmumu darbā, tostarp fabrikā «Provodṇik». Tieši ar Rīgu saistītajās vācbaltiešu studentu korporācijās bija novērojama korporatīvo aprindu saistība ar uzñēmējdarbību. Protams, te sava loma bija arī Rīgas Politehnikumam / Rīgas Politehniskajam institūtam, kur varēja iegūt atbilstošu izglītību [38].

4. attēls. Karls Hans Ēmans. 20. gadsimta sākumā [39].

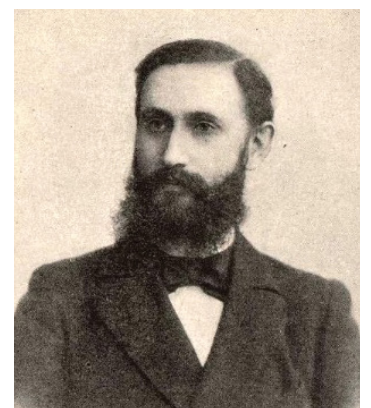

No studentu korporācijas «Fraternitas Baltica» fabrikā «Provodṇik» strādāja vēl astoṇi RPI sagatavotie diplomētie k,īmiķi. 1882. gada absolvents Nikolajs Ports (Nikolai Pohrt; 1854-?) kluva par fabrikas darbinieku 1899. gadā, 1892. gada absolvents Ervins Broks (Erwin Brock; 1864-?) - jau 1892. gadā. Viṇš 1908. gadā sāka vadīt fabrikas Linel̦las ražošanas nodal̦u. 1899. gada absolvents Hermanis Dzenne (Hermann Dsenne; 1869-1937) savu karjeru fabrikā sāka 1904. gadā kā kî̄miķis, vēlāk bija nodaḷas vadītājs, viṇa studiju biedrs Frīdrihs Reinfelds
Fabrikas

«Provodnik»

darbība Rīgā un tās darbinieki - Rīgas

Politehnikuma /

Rīgas Politehniskā

institūta absolventi 
(Friedrich Reinfeld; 1872-?) ķīmiķa amatā nostrādāja trīs gadus - no 1902. gada vasaras līdz 1905. gada novembrim. No 1902. gada septembra līdz 1903. gada augustam viṇiem k̦īmiķa amatā pievienojās 1903. gada absolvents Volfgangs Vahtsmūts (Wolfgang Wachtsmuth; 1876-1964). 1895. gada absolvents Ernsts fon Reisners (Ernst von Reusner; 18691897) ķ̣imiķa amatā strādāja neilgi (1896-1897), jo saslima ar tīfu un nomira. 1896. gada absolvents Georgs Bušteds (Georg Boustedt; 1867-?) tūdal pēc studijām strādāja Kabel̦u nodal̦ā, vēlāk - citās nodaḷās, bet 1898. gadā sāka darbu citā fabrikā. Vina studiju biedrs Džeimss Hākens (James Haken; 1864-?) bija strādājis ārpus tagadējās Latvijas teritorijas, bet 1905. gadā ieradās Rīgā un iestājās darbā fabrikā «Provodṇik». Lauksaimniecības nodalıs 1899. gada absolvents Edgars fon Pikards (Edgar von Pickardt; 1876-1973) fabrikā darbojās neilgi - no 1903. gada novembra līdz 1904. gada septembrim. Bez tam no korporācijas «Fraternitas Baltica» nāca vēl daži darbinieki, kas augstskolas diplomu nebija ieguvuši Rīgā. Johannes Hauzens (Johannes Hausen; 1864-?), kurš bija studējis mehāniku un laboratorijas kursu tehniskajā mehānikā apguva Drēzdenē pie pazīstamā profesora Karla Ernsta Hartiga (Karl Ernst Hartig; 1836-1900) un bija praktizējies kokvilnas ražošanā, 1902. gadā kḷuva par «Provodṇik» direktora palīgu. 1899. gadā Sarkandaugavas fabrikā savas darba gaitas sāka bijušais Mašinnu inženieru un Inženieru nodal̦as students, Mitveidas tehnikuma Saksijā absolvents Teodors Kitels (Theodor Kittel; 1862-?) un Hugo Kleinbergs (Hugo Kleinberg; 1866-?), kurš bija studējis Lauksaimniecības nodạ̦ā (1886-1892) [40]. Starp citu, H. Kleinbergs 1923. gadā kḷuva par iepriekš minētās jaunizveidotās gumijas manufaktūras «Kontinents» tehnisko direktoru.

No otras RP dibinātās (1869) vācbaltiešu studentu korporācijas «Concordia Rigensis» nāca jau iepriekš pieminētais A. fon Hertvigs. Par «Provodṇik» nodal̦u vadītājiem strādājuši šādi korporācijas «Concordia Rigensis» biedri: no 1912. līdz 1914. gadam RPI Mehānikas nodaḷas 1911. gada absolvents - Ernsts Tìls (Ernst Thiel; 1886-?); no 1904. līdz 1914. gadam RP Ķīmijas tehniskās nodal̦as 1891. gada absolvents Karls Lēvende (Karl Loewende; 1860-?); RPI Kīmijas nodal̦as 1908. gada absolventi: no 1909. līdz 1914. gadam Teodors Gīze (Theodor Giese; 18801915) un inženieris Voldemārs Ptašnikovs (Woldemar Ptaschnikow; Mehānikas nodaḷas 1899. gada absolvents Vilhelms Makprangs (Wilhelm Mackprang; 1876-?) strādāja inženiera amatā, savukārt kādreizējais students Jūliuss Štrauss (Julius Strauss; 1875-?) bija grāmatvedis «Provodnnik» filiālē Samarā [41]. Vēl viens korporācijas filistrs, Inženieru nodalıas 1893. gada absolvents un RPI docents (1906-1918) Oskars Hakels (Oskar Hackel; 1864-1920) no 1906. gada bija fabrikas tehniskais padomnieks (padomdevējs) [42]. 
Darbinieku skaitā bijuši arī vēl šādi kādreizējie «politehniḳi»: Komercijas nodaḷas 1898. gada absolvents Nikolajs (Nota) Ginsburgs (Nikolai (Nota) Ginsburg; 1873-?) - fabrikas pilnvarotais Pēterburgā (no 1900), Mehānikas nodal̦as 1914. gada absolvents, raksešu konstruktors un astronautikas celmlauzis Frīdrihs Canders (Friedrich Zander; 1887-1933); bijušie studenti: Pāvils Fedotovskis (Павел Федотовский; 1886-?) korespondents (no 1910), Viljams Heins (William Hein; 1854-?) [43] un Erihs Lange (Erich Lange; 1878-?), Nikolajs Benke (Nikolai Böhnke; 1881- ?), kurš no 1908. gada bija fabrikas grāmatvedis un kontrolieris Rīgā, Samārā, Taškentā, Pēterburgā [44]. Nodaḷas vadītāja (1914-1915) un tehniskā direktora (1915-1919) amatus pildīja būvinženieris Maksimiliāns Krastiṇš (1883-?), Braunšveigas Tehniskās augstskolas absolvents (1912), kurš studijas sāka RPI, bet, acīmredzot, 1905. gada revolūcijas notikumu dẹl uz laiku slēgtajā institūtā neatgriezās un augstskolas diplomu ieguva Vācijā [45].

«Provodṇik» nodaḷas vadītājs Rīgā un Maskavā (1905-1918) bija Arnolds Šilinskis (Arnold Schilinzky; 1878-1927), Kīmijas nodaḷas 1906. gada absolvents, kurš pēc Latvijas Republikas nodibināšanas strādāja par privātskolotāju matematikā, bet mūža nogalē bija Rīgas pilsētas vācu vidusskolas skolotājs un inspektors (1922-1927) [46].

5. attēls.

Arnolda Šilinska autobiogrāfija (ap 1919) [46].

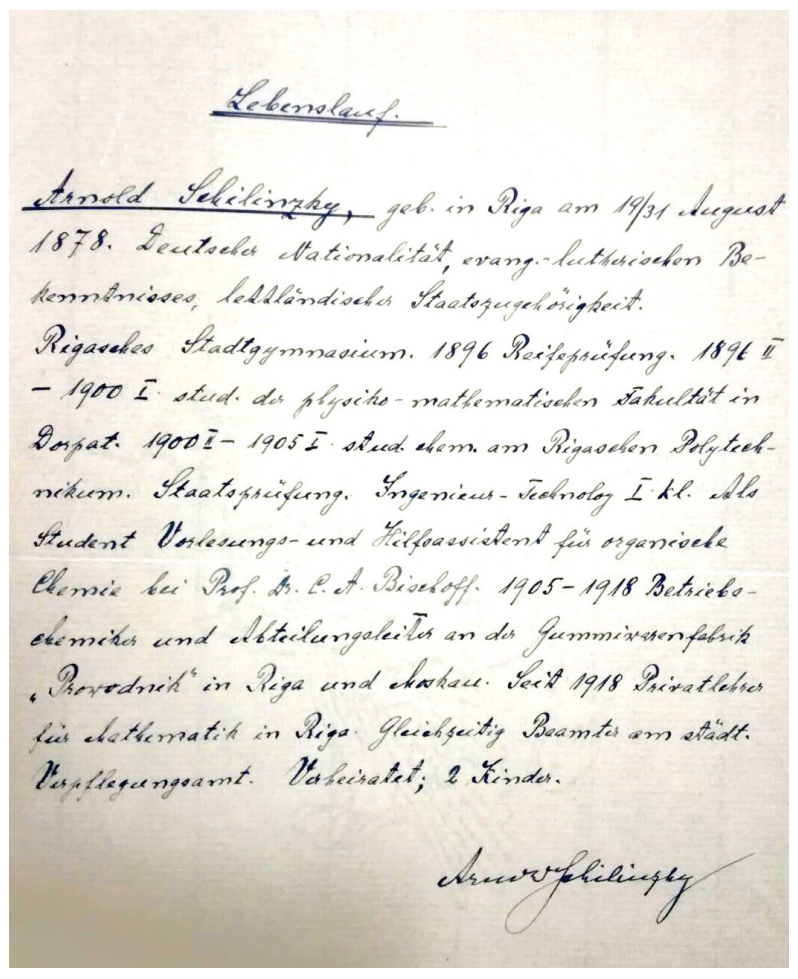

Fabrikas

«Provodnik»

darbība Rīgā un tās darbinieki - Rīgas

Politehnikuma /

Rīgas Politehniskā

institūta absolventi 


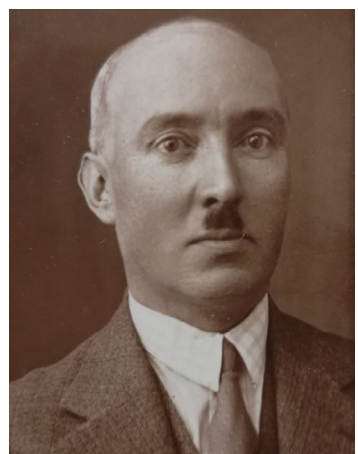

6. attēls. Nikolajs Brinkenhofs (ap 1927). [48].

Zināms, ka Komercijas nodaḷas 1908. gada absolvents Nikolajs Brinkenhofs (Nikolai Brinckenhoff; 1885-?) tūdal pēc RPI absolvēšanas sāka strādat par grāmatvedi un korespondentu fabrikā «Provodṇik». Starpkaru laikā vin,š bija arī uzṇēmuma direktors [47].

\section{Nobeigums}

Fabrika «Provodṇik» 19. gadsimta beigās un 20. gadsimta sākumā bija Sarkandaugavas sirds, un bija raksturīgākais uzṇēmums šajā Rīgas rajonā. Savas darba gaitas te bija sākuši daudzi latvieši, kas no laukiem iebrauca Rīgā, un inženieri, vismaz trīs desmiti RP / RPI absolventu un bijušo studentu, kuru vidū galvenokārt bija vācbaltieši. Fabrikai Sarkandaugavā bija tikpat liela nozīme kā «Baltijas vagonu fabrikai» Grīziṇkalnā. Vēlāk Sarkandaugavā nozīmīga loma bija arī alus darītavai «Aldaris», bet «Provodṇik» darbojās daudz plašākā mērogā, nodrošinot ne tikai tagadējās Latvijas, bet visas cariskās Krievijas un daḷēji ārzemju patērētāju pieprasījumu pēc dažādām precēm. Fabrikas telpās darbojušies daudzi un dažādi uzṇēmumi: 1940. gadā rudenī mehāniskais uzṇēmums «Sorobins» [49], Otrā pasaules kara laikā - lidmašīnu remonta darbnīca [50], no 1946. gada - Rīgas elektromašīnbūves rūpnīca (RER), kurā ir strādājuši un joprojām strādā Rīgas Tehniskajā universitātē (līdz 1990 - RPI) absolventi, tostarp viens no raksta autoriem - O. Šapovalovs.

Rīgā augstāko izglītību ieguvušie inženieri devuši nozīmīgu ieguldījumu fabrikas darbībā un attīstībā. Tas atspogul,ots arī fabrikas «Provodņik» / Rīgas elektromašīnbūves rūpnīcas muzeja ekspozīcijā. 


\section{AVOTU UN LITERATŪRAS SARAKSTS}

[1] «Prowodnik» company, Riga. Riga [1907], p. 3.

[2] Zemgalietis V. Latvijas rūpniecības jaunie ceḷi. Zemgales Balss, 1937, Nr. 60, 4. lpp.

[3] Latvijas Valsts vēstures arhīvs (turpmāk - LVVA) 1773. f., 1. apr., 982. l., 13. Ip

[4] «Prowodnik» company, Riga. Riga [1907], p. 4, 13, 20.

[5] LVVA 1773. f., 2. apr., 9. l., 6. lp.

[6] Cimmermanis M. Mūsu gumijas rūpniecība. Ekonomists, 1929, Nr. 7, 1. lp.

[7] The Prowodnik Works at Riga. Pieejams: http://archive.commercialmotor.com/article/24th-september-1908/3/the-prowodnik-works-at-riga [skatīts: 24.01.2018]

[8] Shapovalov 0. Roman s «Provodnikom». Riga, 2017, s. 8.

[9] Zemgalietis V. Latvijas rūpniecības jaunie ceḷi. Zemgales Balss, 1937, Nr. 60, 4. lpp.

[10] Streiku kustība. Dzimtenes Vēstnesis, 1913, Nr. 162, 3. lpp.

[11] Shapovalov O. Roman s «Provodnikom». Riga, 2017, s. 125.

[12] Rìgas zinas. Balss, 1906, Nr. 96, 2. lpp.

[13] Lokales. Libausche Zeitung, 1914, Nr. 226, S. 3.

[14] «Prowodnik» company, Riga. Riga [1907], p. 4.

[15] Veiss E. A. J. Rīgas Politechniskais institūts 100 gados. Technikas Apskats, 1962, Nr. 35, 4. lpp.

[16] LVVA 1773. f., 1. apr., 3. 1., 325. lpp.

[17] «Provodņika» atjaunošana. Latvijas Tirgotājs, 1921, Nr. 5, 6. lpp.

[18] LVVA 1773. f., 1. apr., 1. 1., 1. lp.

[19] Mūsu rūpniecības atjaunošana. Valdības Vēstnesis, 1921, Nr. 119, 2. lpp.

[20] «Provodnik». Segodna, 1921, Nr. 291, 1.lpp.

[21] Darba dzīve. Krievijas Cīna, 1923, Nr. 77, 4. lpp.

[22] Latvijas gumijrūpniecība. Latvijas Tirgotājs, 1930, Nr. 1/2, 52. lpp.

[23] «Provodṇika» atklāšana atlikta. Amerikas Atbalss, 1921, Nr. 43, 2. lpp.

[24] «Prowodnik»in schweizerischen Händen. Libausche Zeitung, 1924, Nr. 266, S. 2.

[25] Rūpniecība atjaunojas. Krievijas Cīnna, 1924, Nr. 26, 3. lpp.

[26] LVVA 7064. f., 1. apr., 2. l., 12.-13. lp.

[27] Kiesners A. Lielais ugunsgrēks Sovtorgflota linu noliktavās - bij. Provodņika fabrikā. Ugunsdzēsējs, 1930, Nr. 6, 439. lpp.

[28] Krievu-franču gumijas, guttaperčas un telegr. pied. fabr. s-ba zem firmas «Provodṇiks» likvidācija. Ekonomists, 1935, Nr. 22, 873. lpp.

[29] Jaunas telpas tenisa spēlei. Jaunākās Ziñas, 1937, Nr. 19, 3. lpp.

[30] Labi sasniegumi LSOS pārbaudes sacīkstes. Rīts, 1936, Nr. 144, 4. lpp.

[31] Gaisa satiksmi Rīga-Liepāja atklās nākamā pavasarī. Rīts, 1935, Nr. 204, 1. lpp. 
[32] Festschrift zum fünfzigjährigen Jubiläum des Rigaschen Polytechnischen Instiuts, 1862-1912. Riga: W. F. Häcker, 1912, Tab. 1.

[33] LVVA 1773. f., 1. apr., 982. l., 13. lp.

[34] Arnold von Hertwig. Rigasche Rundschau, 1928, Nr. 50, S. 7.

[35] LVVA 2996. f., 6. apr., 1612. l., 3.lp.

[36] Rīgas Politechnikums, 1862.-1919. g. Album Academicum (1912.1919. g.). Rīga: Latvijas Universitātes Studentu grāmatnīcas izdevums, 1938, 289. lpp.

[37] Spiski shertv. Pieejams: http://lists.memo.ru/d38/f85.htm [skatīts: 21.01.2018].

[38] Cerūzis, R. Vācu faktors Latvijā (1918.-1939.): politiskie un starpnacionālie aspekti. Promocijas darbs. Rīga: LU Vēstures un filozofijas fakultāte, 2002, 310. lpp.

[39] Karls Hans Ēmans, 21. gs. sākumā.«Provodṇik»/RER muzeja krājums.

[40] Rosenkranz, M., Stieda, E. (Hrs.). Album der Landsleute der Fraternitas Baltica, 1865-1910. Riga, 1910, S. 60, 68, 69,83, 84, 91, 94-96, 104, 117, 122, 123.

[41] Concordia Rigensis: 29.11.1869-29.11.1969 : Festschrift : Chronik, Album, Statistisches. Hamburg: Philisterverband der Concordia Rigensis, 1969, S. 86, 90, 104, 112, 116, 121.

[42] Album Academicum des Polytechnikums zu Riga, 1862-1912. Riga: Jonck \& Poliewsky, 1912, S. 169.

[43] Neujahr 1908. Rigasche Zeitung, 1908, Nr. 1, S. 8.

[44] Album Academicum des Polytechnikums zu Riga, 1862-1912. Riga: Jonck \& Poliewsky, 1912, S. 322, 497, 512, 567.

[45] LVVA 1303. f., 3. apr., 19. 1., 145. lp.

[46] LVVA 1632.f., 1. apr., 20784. l.

[47] LVVA 1773. f., 1. apr., 3. 1., 3. lp.

[48] LVVA 3234. f., 33. apr., 24057. 1.

[49] Var pieteikties traktoru vadītāju kursos. Cīna, 1940, Nr. 104, 10. lpp.

[50] Elmārs T. Sarkandaugavā. Cīna, 1944, Nr. 66, 2. lpp.

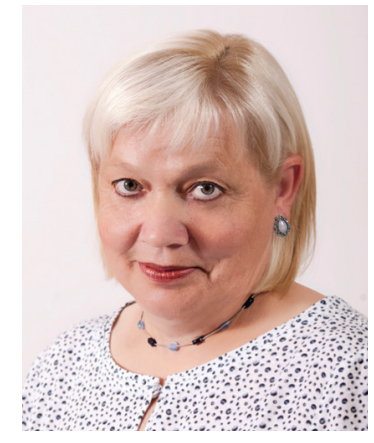

ALĪDA ZIGMUNDE, Dr. paed., has been a Specialist at the Museum of Riga Technical University since 1989. From 2007 to 2015, she was a Senior Researcher. She is currently a Professor at the Institute for Humanities and Head of the Department for Historic Research and Scientific Publications of the RTU Research Centre for Engineering History. Her main academic interests include the history of pedagogy in Europe, the history of the institutions of education and of private schools, and the history of pedagogy of universities, history of engineering sciences and universities.

Address: 1 Kronvalda Boulevard, Riga, LV-1010, Latvia

Phone: +371 29869642

E-mail: alida.zigmunde@rtu.lv 


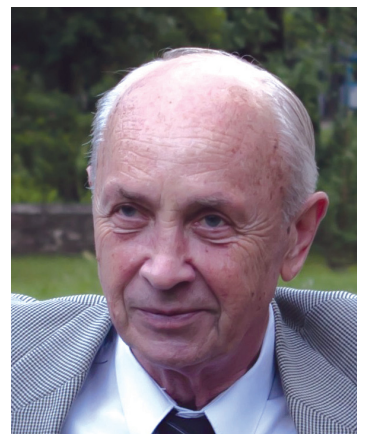

OLEGS ŠAPOVALOVS, Dr. sc. ing., graduated from RPI in 1959, directed to work at Riga Electromachine Building Factory (RER). Previously he had been the team leader, SKB chief engineer, deputychief engineer of RER, director of privatization. He received a degree of Candidate of Science in 1968, and the Dr.sc ing. degree in 1992. He was a docent at RPI in 1993. Lately he is engaged in the activities of the «Provodnik» / RER museum. He has written the book «Roman with «Provodnik»» in 2017.

Address: 15 Hāpsalas Street 15, Flat 98, Riga, LV-1005, Latvia

Phone: +37120396320

E-mail: oleg_shapovalov@inbox.lv

Alīda Zigmunde, Oḷegs Šapovalovs

\section{The Activities of Factory «Prowodnik» in Riga and its Employees - Graduates of the Riga Polytechnicum / Riga Polytechnic Institute}

The article gives an overview of the activities of rubber, gutta-percha and telegraph factory «Prowodnik» in Riga, founded in 1888. Before the First World War, the factory was one of the four largest rubber factories in the world. During the First World War, in 1915, the factory was evacuated to Moscow, in 1918, it was expropriated. In 1921, the shareholders decided to re-establish «Prowodnik» in its old premises in Riga, but the economic situation had changed. For some years it operated as a woodworking factory (1925-1935), but it never reached the boom it had experienced at the end of the 19th century and at the beginning of the 20 th century. At the end of the 1930s the factory was liquidated. The alumni of the Riga Polytechnicum (RP) and Riga Polytechnic Institute (RPI) who had given significant input in its achievements have been identified by the authors of this article.

Keywords. «Prowodnik», Riga Polytechnicum, Riga Polytechnic Institute, alumni in industry.

Алида Зигмунде, Олег Шаповалов

\section{Работа предприятия «Проводник» в Риге и его персонал - выпускники Рижского политехникума / Рижского политехнического института}

В статье приводится обзор деятельности созданного в 1888 году в Риге на Саркандаугаве русско-французского совместного предприятия по изготовлению резиновых, гуттаперчевых и телеграфных изделий товарищества «Проводник». До Первой мировой войны оно стало одним из четырех крупнейших в мире резиновых фабрик. В 1915 году фабрику эвакуируют в Москву, в 1918 году национализировали. В 1921 году 
акционеры решили в Латвии восстановить работу бывшего «Проводника», но ситуация изменилась. Многие годы фабрика проработала как деревообрабатывающее предприятие (1925-1935), но никогда не достигло такого развития, как в конце 19-го, начале 20-го веков. В конце 30-х годов предприятие ликвидировано. Существенный вклад в работу и развитие «Проводника» внесли выпускники Рижского политехнического института, о чем узнали авторы статьи из документов при проведении исследований.

Ключевые слова: «Проводник», Рижский политехникум, Рижский политехнический институт, выпускники на производстве. 